\title{
A Simple \& Convenient Solid Phase Synthesis of Bacterial Origin Octapeptide Sequence, Glu-Asp-Gly-Asn-Lys-Pro-Gly-Lys-OH
}

\author{
Riaz A. Khan
}

Accepted: 28 January 2010/Published online: 3 March 2010

(c) The Author(s) 2010. This article is published with open access at Springerlink.com

\begin{abstract}
The repeating octapeptide sequence, Glu-AspGly-Asn-Lys-Pro-Gly-Lys-OH derived from the glycoprotein found in Staphylococcus aureus cell wall is assembled by simple solid phase peptide synthesis methodology using a base labile linker.
\end{abstract}

Keywords Phencyl bromide - Protein-A fragment · Staphylococcus aureus · Bacterial cell wall · Octapeptide · Antibacterial · Base labile linker · Manual SPPS

Protein-A, a glycoprotein obtained from Staphylococcus aureus Cowen 1. bacterial cell wall (Kronvall and Gewurz 1970) appears to be working against toxicity of certain chemical exposure (Dohadwala and Ray 1985; Singh et al. 1990) and is a potent immunomodulator (Catalona et al. 1981). It has been shown to ameliorate toxicity of cyclophosphamide, carbon tetrachloride, bacterial endotoxins (Ray et al. 1984; Kerbel and Davies 1974) and have been demonstrated to regress primary tumors in rodent and mammalian models through modulating the reactivity of cellular and humoral factors (Atherton and Sheppard 1985). The octapeptide Glu-Asp-Gly-Asn-Lys-Pro-GlyLys-OH was found to be the repeating sequence in proteinA structure. Toxicology and other biological studies prompted to synthesize the sequence albeit using a very simple and convenient method inspired from Merrifield's' original synthesis.

The octapeptide sequence was assembled (Scheme 1) using a base labile linker (Katti et al. 1992). The first amino

R. A. Khan ( $\square)$

Department of Chemistry, Manav Rachna International

University (MRIU), Faridabad, HR, India

e-mail: Riazkhan09@hotmail.com acid lysine was anchored from C-terminal to amino methyl resin as its $t$-Boc derivative. The linker was synthesized starting from phencyl bromide, which, in turn, was prepared from acetophenone and bromine using aluminium chloride under extra cooled conditions $\left(-78^{\circ} \mathrm{C}\right)$. The phencyl bromide (2) was coupled with chloroacetic acid and it was further extended by reacting with 2-mercaptoethanol to give the full-length liker (6). The linker (6) was coupled with $t$-Boc-Lys ${ }^{Z}$ using dicyclohexylcarbodiimide (DCC) and 4-dimethyl aminopyridine (DMAP) to give $t$-Boc-Lys ${ }^{\mathrm{Z}}$-Linker (7) and it was oxidized to sulphone (9) via reduction and subsequent oxidation of the product (8) with potassium per oxomonosulphate (oxone). The oxidized $t$-Boc-Lys ${ }^{\mathrm{Z}}$-Linker (9) was coupled to aminomethyl resin using DCC and 1-hydroxybenzotriazole (HOBt) in dichloromethane-dimethyl formamide $\left(\mathrm{CH}_{2} \mathrm{Cl}_{2}\right.$ DMF), quantified by picric acid method (Rich and Sing 1979; Stewart and Young 1984). The first loading of $t$-BocLys $^{\mathrm{Z}}$-Linker (97.12 micromoles per gram) on solid support was sequentially extended towards n-terminus by single addition of 3-molar equivalents of suitably protected amino acids activated by DCC-HOBt. The protected amino acids were prepared during the study, purified by recrystallization and well characterised by thorough comparison with authentic reference samples. The $t$-Boc, Z, benzyl, methyl ester groups were employed in protecting the amino and carboxyl groups in amino acids i.e., Lys (Klieger and Gibian 1962; Schwyzer and Rittel 2004; Bezas and Zervas 1961), Glu (Bodanszky and Bodanszky 1982; Hirs and Timasheff 1979), Asp (Hirs and Timasheff 1979; Fujino and Hatanaka 1967, Asn (Broadbent et al. 1967), Gly (Moroder et al. 1976) and Pro (Beyerman et al. 1968). The requisite time for each coupling was about $1 \mathrm{~h}$. The assembled peptide sequence was cleaved from the solid support using $5 \%$ aq. sodium hydroxide in dioxane- 
methanol in $68 \%$ yield based on first lysine loading. The protected peptide obtained as yellowish syrup was thoroughly washed with organic solvents $\mathrm{CH}_{2} \mathrm{Cl}_{2}, \mathrm{CHCl}_{3}$, $\mathrm{CHCl}_{3}-\mathrm{MeOH}(5 \%)$, brine and dichloromethane and was deprotected in $5 \mathrm{~N} \mathrm{HCl-dioxane}$ with thioanisole and ethanedithiol (EDT) as scavengers and crude yield of the peptide was $87 \%$. The octapeptide showed remarkable order of antifungal activity at micromolar dose levels in initial testing against Candida albicans.

\section{Experimental}

Amino acids and aminomethyl resin were from purchased from Sigma Chemical Co. USA and Merck Darmstadt, Germany, respectively. Amino acids except Gly were of L configuration. Homogeneity of amino acids and peptides was established on TLC silica gel G plates (precoated from Merck) in BuOH:AcOH: $\mathrm{H}_{2} \mathrm{O}$ (25:5:10), BuOH:Pyridine: $\mathrm{AcOH}: \mathrm{H}_{2} \mathrm{O}$ (9:8:6:7), $\mathrm{CHCl}_{3}: \mathrm{MeOH}: \mathrm{H}_{2} \mathrm{O}$ (25:3:2). Synthesis was carried out in 3-necked sintered and suction outlets fitted $500 \mathrm{ml}$ RB flask with manual solid phase synthesis (Merrifield 1963).

\section{Preparation of Phencyl Bromide (2)}

To a solution of acetophenone $(\mathbf{1}, 49 \mathrm{~g})$, cooled in acetoneliquid nitrogen at $-78^{\circ} \mathrm{C}$ was added bromine $(20 \mathrm{ml})$ drop wise with vigorous stirring over $30 \mathrm{~min}$. When color of bromine disappeared and a pinkish reaction mixture with crystals appeared, it was filtered, water and ether washed quickly, dried under vacuum to give the phencyl bromide $(2,46 \mathrm{~g})$, m. p. $48^{\circ} \mathrm{C}$.

Preparation of $\mathrm{C}_{6} \mathrm{H}_{5} \mathrm{C}(\mathrm{O}) \mathrm{CH}_{2} \mathrm{C}-\mathrm{O}-\mathrm{CH}_{2}-\mathrm{S}-\left(\mathrm{CH}_{2}\right)_{2}-\mathrm{OH}(6)$

Prepared according to Katti et al. (1992).

Preparation of Boc-Lys ${ }^{\mathrm{Z}}-\mathrm{O}-\left(\mathrm{CH}_{2}\right)_{2}-\mathrm{S}-\mathrm{CH}_{2}-(\mathrm{O})-\mathrm{C}-\mathrm{O}-$ $\mathrm{CH}_{2}-\mathrm{C}(\mathrm{O})-\mathrm{C}_{6} \mathrm{H}_{5}(7)$

Boc-Lys ${ }^{\mathrm{Z}}(5.8 \mathrm{~g})$ in dry $\mathrm{CH}_{2} \mathrm{Cl}_{2}$ was mixed with Linker $(6,3.8 \mathrm{~g})$ and DCC (3.1 g), DMAP (250 mg) under stirring at $0^{\circ} \mathrm{C}$ and stirring continued for $2 \mathrm{~h}$ at $0^{\circ} \mathrm{C}$. A syrupy material was obtained and was devoid of $\mathrm{CH}_{2} \mathrm{Cl}_{2}$ under vacuum and the solid residue was taken in EtOAc, water washed, dried over $\mathrm{Na}_{2} \mathrm{SO}_{4}$, EtOAc evaporated to give Boc-Lys ${ }^{\mathrm{Z}}$-Linker (7, 7.1 g).
Scheme 1 Schematic representation of synthesis

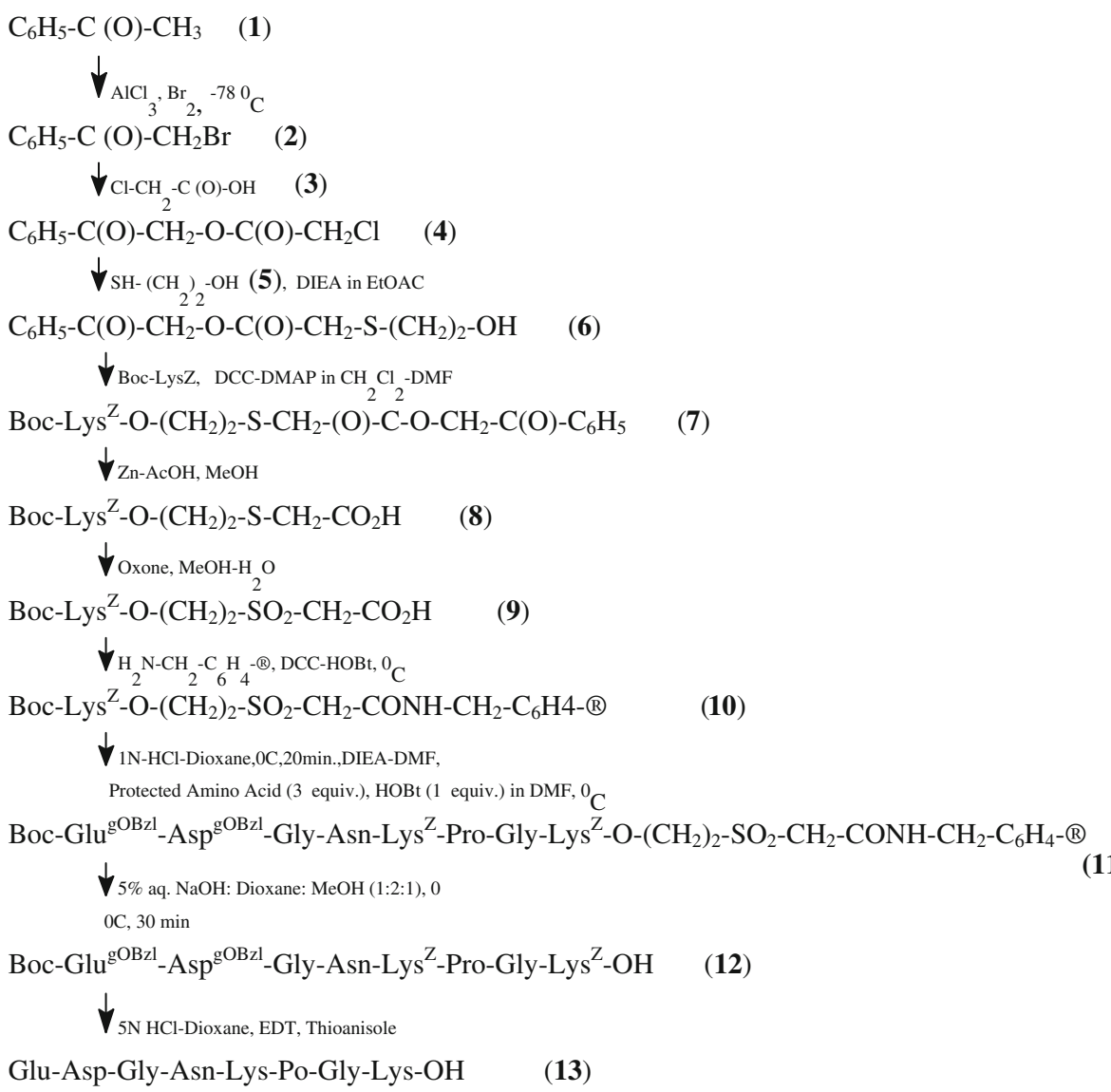


Boc-Lys ${ }^{\mathrm{Z}}-\mathrm{O}-\left(\mathrm{CH}_{2}\right)_{2}-\mathrm{S}_{-} \mathrm{CH}_{2}-\mathrm{CO}_{2} \mathrm{H}(\mathbf{8})$

To a solution of $(7,2.2 \mathrm{~g})$ in $\mathrm{MeOH}(30 \mathrm{ml})$ was added acetic acid $(2 \mathrm{ml})$ and a pinch of Zinc dust under stirring at RT After $1 \mathrm{hr}$. the mixture was filtered and syrup obtained was dissolved in EtOAc, washed with water and organic layers combined, dried over anhydrous $\mathrm{Na}_{2} \mathrm{SO}_{4}$ and evaporated to give $(\mathbf{8})$ as oil, $1.0 \mathrm{~g}$.

Boc-Lys ${ }^{\mathrm{Z}}-\mathrm{O}-\left(\mathrm{CH}_{2}\right)_{2}-\mathrm{SO}_{2}-\mathrm{CH}_{2}-\mathrm{CO}_{2} \mathrm{H}(\mathbf{9})$

To the stirring solution of $(\mathbf{8}, 1 \mathrm{~g})$ in $\mathrm{MeOH}$ was added oxone ( $0.60 \mathrm{~g}$ in $5 \mathrm{ml}$ water) and stirring continued for $1 \mathrm{~h}$ at RT. Reaction mixture was extracted with EtOAc, $\mathrm{H}_{2} \mathrm{O}$ washed and organic layer concentrated in vacuum to yield (9, $1.2 \mathrm{~g})$.

Boc-Lys ${ }^{\mathrm{Z}}-\mathrm{O}-\left(\mathrm{CH}_{2}\right)_{2}-\mathrm{SO}_{2}-\mathrm{CH}_{2}-\mathrm{CONH}-\mathrm{CH}_{2}-\mathrm{C}_{6} \mathrm{H}_{4}-{ }^{\circledR}(\mathbf{1 0})$

Aminomethyl resin $(2 \mathrm{~g})$ swelled in $\mathrm{CH}_{2} \mathrm{Cl}_{2}$ was coupled with Boc-Lys ${ }^{\mathrm{Z}}-\mathrm{O}-\left(\mathrm{CH}_{2}\right)_{2}-\mathrm{SO}_{2}-\mathrm{CH}_{2}-\mathrm{CO}_{2} \mathrm{H}(\mathbf{9}, 1.0 \mathrm{~g})$ in $\mathrm{CH}_{2} \mathrm{Cl}_{2}$-DMF (1:1, $\left.50 \mathrm{ml}\right)$ under vigorous stirring using DCC (500 mg) and HOBt (400 mg) dissolved in $\mathrm{CH}_{2} \mathrm{Cl}_{2}$ at $0^{\circ} \mathrm{C}$ for $4 \mathrm{~h}$. The coupling was repeated by adding more DCC $(500 \mathrm{mg})$ and $\mathrm{HOBt}(400 \mathrm{mg})$ with stirring for 2 more hours. The unreacted Boc-Lys ${ }^{\mathrm{Z}}-\mathrm{O}-\left(\mathrm{CH}_{2}\right)_{2}-\mathrm{SO}_{2}-$ $\mathrm{CH}_{2} \mathrm{CO}_{2} \mathrm{H}$ was detected by TLC after final loading and the coupled resin was washed with DMF, $\mathrm{CH}_{2} \mathrm{Cl}_{2}, \mathrm{MeOH}$ and DMF (25 ml each).

\section{Sequence Loading and Quantitation}

Picric acid method was used to quantify the loading of resin. The unbound amino endings were capped with $\mathrm{Ac}_{2} \mathrm{O}-\mathrm{DMAP}$. The resin was washed with $\mathrm{CH}_{2} \mathrm{Cl}_{2}$ and DMF $(20 \mathrm{ml} \times 2)$ and quantified to $91 \%(712 \mathrm{mM} / \mathrm{g})$ ready for coupling. The suitably protected amino acids were coupled to solid support in the following manner, (1) the cleavage of $t$-Boc group was carried out using $1 \mathrm{~N} \mathrm{HCl}$ in dioxane at $0^{\circ} \mathrm{C}$, neutralized with DIEA and coupled using DCC-HOBt in DMF: $\mathrm{CH}_{2} \mathrm{Cl}_{2}(1: 1)$ at $0^{\circ} \mathrm{C}$, (2) after each coupling and deprotection, the resin was washed with DMF: $\mathrm{CH}_{2} \mathrm{Cl}_{2}(1: 1,15 \mathrm{ml} \times 2,5 \mathrm{~min}$ each), (3) prior to every deprotection, the coupling was monitored by picric acid method and allowed to proceed to completion generally within $2 \mathrm{~h}$.

\section{Sequence Release and Purification}

The peptide was released from solid support with $5 \%$ aq. $\mathrm{NaOH}$-dioxane- $\mathrm{MeOH}(1: 2: 1,20 \mathrm{ml})$ at $0^{\circ} \mathrm{C}$ for $0.5 \mathrm{~h}$. The crude peptide was kept in $5 \mathrm{~N} \mathrm{HCl-dioxane}$ with ethanedithiol and thioanisole for $0.5 \mathrm{~h}$ to yield the (naked) peptide which was washed with dichloromethane, diethyl ether and purified by column chromatography using Sephadex LH-20 in $\mathrm{MeOH}$ and water: $\mathrm{MeOH}$ (65:35) with fractions pooled and lyophilized to give a transparent oil, $4.41 \mathrm{~g}, 73 \%$, TLC:single spot, BuOH:AcOH: $\mathrm{H}_{2} \mathrm{O}$ (25:5:10), Rf 5, Ninhydrin. FAB-MS (m/z): $843(\mathrm{M}+)$ corroborated the structure.

Open Access This article is distributed under the terms of the Creative Commons Attribution Noncommercial License which permits any noncommercial use, distribution, and reproduction in any medium, provided the original author(s) and source are credited.

\section{References}

Atherton E, Sheppard RC (1985) Solid phase peptide synthesis using $\mathrm{N} \alpha$-fluorenylmethoxycarbonylamino acid pentafluorophenyl esters. J Chem Soc Chem Comm 3:165-166

Beyerman MHC, Boers-Boonekamp AM, Brink-zimmermannova HMVD (1968) Rev Trav Chem 87:257-273

Bezas B, Zervas L (1961) On the peptides of L-lysine. J Am Chem Soc 83:719-722

Bodanszky M, Bodanszky A (1982) The practice of peptide synthesis. Springer, Berlin

Broadbent W, Morley JS, Stone BE (1967) Polypeptides. Part V. The use of t-butyl 2,4,5-trichlorophenyl carbonate in the synthesis of $\mathrm{N}$-t-butoxycarbonyl amino-acids and their 2,4,5-trichlorophenyl esters. J Chem Soc (C), 2632-2636

Catalona WJ, Ratliff TI, McCool RE (1981) Interferon induced by S. aureus protein A augments natural killing and ADCC. Nature 291:77

Dohadwala M, Ray PK (1985) In vivo protection by protein A of hepatic microsomal mixedoxygenase system of cyclophosphamide treated rats. Cancer Chemother Pharmacol 14:135-138

Fujino M, Hatanaka C (1967) A new reagent for the tertbutyloxycarbonylation of amino acids. Chem Pharm Bull (Tokyo) 15:2015-2016

Hirs CHW, Timasheff SN (eds.) (1979) Methods in Enzymol XLVII:501-578

Katti SB, Misra PK, Haq W, Mathur KB (1992) A new base-labile linker for solid-phase peptide synthesis. J Chem Soc Chem Commun 11:843-844

Kerbel RS, Davies AJ (1974) The possible biological significance of Fc receptors on mammalian lymphocytes and tumor cells. Cell 3:105-112

Klieger E, Gibian H (1962) Über Peptidsynthesen, X. Vereinfachte Darstellung und Reaktionen von Carbobenzoxy-1-glutaminsäure$\alpha$-halbestern. Justus Liebigs Annalen der Chemie 655:195-210

Kronvall G, Gewurz J (1970) Activation of IgG activated complement fixation by staphylococcal protein A. Clin Exp Immunol 7:211-220

Merrifield RB (1963) Solid phase peptide synthesis. I. The synthesis of a tetrapeptide. J Am Chem Soc 85:2149-2154

Moroder L, Hallet A, Wunsch E, Keller O, Wersin G (1976) Di-tert.butyl-dicarbonate, a useful tert.-Butyloxycardonylating reagent. Hoppe Seylers Z Physiol Chem 357:1651-1653

Ray PK, Bandyopadhyay S, Dohadwala M, Canchanapan P, Mobini J (1984) Antitumor activity with nontoxic doses of protein A. Cancer Immunol Immunother 18:29-34

Rich DH, Sing J (1979) The peptides, analysis, synthesis, biology. In: Gross E, Meinhofer (eds) vol I, Academic Press, New York, p 241 
Schwyzer R, Rittel W (2004) Synthese von Peptid-Zwischenprodukten für den Aufbau eines corticotrop wirksamen Nonadecapeptids. I. $\mathrm{N}^{\varepsilon}$-t-Butyloxycarbonyl-L-lysin, $\quad \mathrm{N}^{\varepsilon}-\left(\mathrm{N}^{\varepsilon}\right.$-t-Butyloxycarbonyl-Llysyl)- $\mathrm{N}^{\varepsilon}$-t-butyloxycarbonyl-L-lysin, $\mathrm{N}^{\varepsilon}$-t-Butyloxycarbonyl-Llysyl-L-prolyl-L-valyl-glycin und Derivate. Helvetica Chimica Acta 44:159-169
Singh KP, Zaidi SI, Raisuddin, Saxena AK, Dwivedi PD, Seth PK, Ray PK (1990) Protection against carbon-tetrachloride-induced lymphoid organotoxicity in rats by protein A. Toxicol Lett 51:339-351

Stewart JM, Young JD (1984) Solid phase peptide synthesis. Pierce Chemical Company, Rockford, IL, USA 